\title{
The Influence of Brand Equity on Consumer's Purchase Decision: A Quantitative study
}

\author{
Muhammad Ilham Wardhana Haeruddin \\ Universitas Negeri Makassar \\ Email: ilham.wardhana@unm.ac.id
}

(Received: January-2021; Reviewed: February-2021; Accepted: February-2021;

Avalaible Online: March-2021; Published: March-2021)

(7) (5) This is an open access article distributed under the Creative Commons Attribution License
CC-BY-NC-4.0 (C)2021 by author (https://creativecommons.org/licenses/by-nc/4.0/)

\begin{abstract}
This study aims to explain influence between the elements of brand equity (Brand Awareness and Brand Loyalty) on Purchasing Decisions. The population in this study were consumers of PT. Semen Tonasa in Pangkep Regency. While the number of samples is as many as 63 respondents who were selected based on purposive sampling technique for two months of research at the Labakkang Jaya Shop. The data collection method used was the distribution of questionnaires that had been tested for validity and reliability. Multiple regression is used to analyize the data. From the regression analysis, the equation $\mathrm{Y}=$ $4.695+0.425 \mathrm{X} 1+0.458 \mathrm{X} 2$ is obtained. The results of this study indicate that Brand Awareness and Brand Loyalty simultaneously have a positive and significant effect on the purchase decision (Y) of Semen Tonasa. The variable of the brand equity element that has the dominant effect on the purchasing decision of Semen Tonasa is Brand Loyalty with a regression coefficient value of 0.458 .
\end{abstract}

Keywords: Brand Awareness; Brand Loyalty; Purchasing Decisions.

\section{INTRODUCTION}

The development of the business world is so fast that business competition is getting tougher, this is indicated by the increasing number of companies that produce similar products to meet consumer needs (Haeruddin et al., 2020). The choice of products that are increasingly circulating in the market makes competition between companies tighter, so that consumers find it difficult to make purchasing decisions. Companies need to study and strive to fully understand the consumer's purchasing decision process, their experiences in learning, selecting, using, and even getting rid of products (Gurley et al, 2005; Haeruddin, 2017).

Consumer purchasing decisions are the result where they feel they have a problem and then go through a rational process of solving the problem (Stankevich, 2017:7). Consumer 
purchasing decisions are consumer preferences for brands in the collection of choices and consumer intentions to buy the most preferred brand (Cobb-Walgren et al, 2013:25). Brands play a very important role, one of which is bridging consumer expectations when the company promises something to consumers. Thus, it can be seen that there is an emotional bond that is created between consumers and companies through brands.

Companies are required to compete competitively in terms of creating and maintaining loyal customers, one of which is through war between brands (Gambetti et al, 2016:90). Companies are increasingly realizing that brands are an important factor in competition and are valuable corporate assets, and one of the company's valuable assets is having strong brand equity (Mudambi, 2002:525). The stronger the brand equity, the greater the attraction to persuade consumers to buy or consume products provided by the company (Musa, 2017). Therefore, purchasing decisions are strongly influenced by brands and consumer perceptions about these brands.

A prestigious brand has a strong brand equity. Brand equity is determined by four main elements, namely brand awareness, brand association, perceived quality, and brand loyalty (Aaker, 2013: 23). With regard to these four variables, producers must first understand consumer behavior before influencing consumers to make purchasing decisions (Prasad et al, 2019:372). According to Supranto and Limakrisna (2011: 43), brand equity is the value determined by consumers in a brand above and beyond the characteristics / functional attributes of the product. Brand equity is the most valuable asset in business in underlying image, personality, identity, attitude, association familiarity and brand awareness (Hasan, 2014: 51). Purchasing decisions made by consumers are decisions made after consumers have analyzed various alternatives or information from a product or service. Brand equity is one factor in brand building. Through strong brands companies can manage their assets well, increase cash flow, expand market share, set premium prices, reduce promotional costs, increase sales, maintain stability, and increase competitive advantage. Based on the consumer's perspective, brand equity is a form of response from consumers to a brand.

Brand awareness is the ability of a brand to appear in the minds of consumers when they are thinking about certain product categories and how easily the name comes up (Shimp, 2003: 9). Brand awareness is a basic dimension in brand equity. is a general purpose of marketing communication, with high brand awareness it is expected that whenever the need for categories arises, the brand will be brought back from memory which is then used as a consideration for various alternatives in decision making.

Durianto (2011: 6), state that the level of brand awareness can be explained as follows:

a. Unaware of Brand is the lowest level in the brand awareness pyramid, where consumers are not aware of a brand.

b. Brand Recognition is the minimum level of brand awareness, where the introduction of a brand appears again after aided recall is carried out.

c. Brand Recall is an unaided recall of a brand because it is different from the recognition task, respondents are not helped to bring up the brand.

d. Top of Mind is a brand that is mentioned first by consumers or which first comes to the mind of consumers. In other words, the brand is the main brand of the various brands that consumers have in mind.

According to Aaker (2013: 26) Brand loyalty is based on the consistent behavior of customers to buy a brand as a form of learning process from customers on the ability of a brand to meet their needs. Brand loyalty reflects the level of relationship between consumers and a product brand. This measure is able to provide an idea of whether or not a customer may switch to another product brand, especially if there is a change in the brand, whether related to price or other attributes. A customer who is very loyal to a brand will not easily transfer his purchase to 
another brand, no matter what happens to that brand. It means that a company can gain profit from them (Helgesen, 2006:245)

Purchasing decisions are actions taken by consumers to purchase a product (Kotler \& Amstrong, 2012:226). Therefore, making consumer purchasing decisions is a process of selecting one of several alternative solutions to problems with real follow-up (Schiffman \& Kanuk, 2010:485). After that the consumer can evaluate the choice and then can determine the attitude to be taken next.

PT. Semen Tonasa is a company engaged in the production of building raw material providers based in South Sulawesi and is well known in this region. PT. Semen Tonasa is currently not a new player in the cement industry sector in Indonesia. PT. Semen Tonasa has succeeded in building a strong enough brand image in the cement commodity market space, not only in South Sulawesi but Kalimantan, Bali, Nusa Tenggara, Maluku, Papua and other regions. However, it cannot be denied that PT. Semen Tonasa is not alone in the cement industry sector in Indonesia, but there are several competitors that are quite competitive.

This large cement demand will create business opportunities to meet the demand for cement in Indonesia. So that it invited several large companies, both foreign and domestic, to take part in the national cement industry. PT Indocement with Tiga Roda leads the national cement market with a market share of $33.1 \%$, followed by PT Semen Gresik under the Semen Gresik brand with around 17\%. Then PT Holcim Indonesia Tbk with its product Holcim cement with a market share of around $15 \%$. PT Semen Padang is also no less big, its product brand, Semen Padang, controls the national market share of $11 \%$. The next sequence is Semen Tonasa with a market share of $8.1 \%$. Semen Bosowa with a market share of 5.2\%. Semen Andalas with a market share of $4 \%$. Then Batu Raja cement with a market share of $2.2 \%$, then finally PT Semen Kupang with a market share of around $1 \%$ which was managed by AMC (Asset Management Company) due to the crisis in the company. But as a group, the Gresik Group (Semen Indonesia) is still the market leader for the national cement market, as it consists of a combination of the companies Semen Gresik, Semen Tonasa and Semen Padang.

If measured from a national scale, Semen Tonasa's market share is actually relatively small, reaching only $8.1 \%$ of the total national cement market share. When compared to Holcim cement which has the third largest market share of $15.2 \%$, it is clear that the market share of Semen Tonasa is small. But basically, PT. Semen Tonasa is the market leader for its home region, namely the eastern part of Indonesia with Semen Tonasa products, where PT Semen Tonasa holds a $45 \%$ market share, Tiga Roda 6.3\%, Holcim 0.2\%, Semen Bosowa 12.8\%, and Conch at $35.7 \%$. The following is the sales data for PT Semen Tonasa:

Table 1. Sales Data of PT Semen Tonasa

\begin{tabular}{ccc}
\hline Year & Sales (Tonnage) & Percentage \\
\hline 2016 & $6,613,192$ & - \\
2017 & $6,400,256$ & $-3,22$ \\
2018 & $6,842,650$ & 6,91 \\
2019 & $7,073,081$ & 3,37 \\
2020 & $7,133,610$ & 0,85 \\
\hline
\end{tabular}

Source: Semen Tonasa AR, 2020

Based on the things that have been explained, it can be seen that PT Semen Tonasa has a relatively small market share on a national scale, this is due to the large number of domestic competitors and the entry of foreign cement companies in Indonesia and this also has an impact on sales of Semen Tonasa, although it is still continues to increase, but the percentage is decreasing, it tends to be closer to a decrease in sales. Therefore, it is very important to know 
how consumers perceive a cement brand in the midst of increasingly competitive cement industry, so that it can become a consumer preference in buying cement. Therefore, it is important for PT. Semen Tonasa to analyze the brand equity of cement tonasa. By knowing the brand equity of Semen Tonasa, the company can know and understand the attitude of its consumers towards the elements of Semen Tonasa brand equity.

\section{METHOD}

This study uses quantitative research by examining 3 variables: Purchasing Decisions, Brand Awareness and Brand Loyalty. The sampling technique used in this research is purposive sampling, where the respondents must meet the following criteria: 1) People who live in Pangkep Regency, and 2) People who have used Semen Tonasa products more than once. Based on these criteria, 63 respondents were obtained who will be used in this study. In the sampling process, researchers distributed questionnaires using a timeframe of two months, starting from March to May 2020 at the Labakkang Jaya Shop, one of the cement retailers in Pangkep Regency.

The respondents were given a questionnaire which would later be tested for validity and reliability. This is necessary because considering that the primary data source is a questionnaire that is very prone to errors or inaccuracies. To analyze the data, multiple regression is used. $\mathrm{T}$ test and $\mathrm{f}$ test are used to test the hypothesis offered.

\section{RESULT AND DISCUSSION}

The results of the validity and reliability test show that all items used in the questionnaire are declared valid and reliable and can be used as research instruments.

Table 2. Equations of Regression Results

\begin{tabular}{ccccc}
\hline Variable & Regression Coefficient & T Count & T Table & Sig. \\
\hline $\begin{array}{c}\text { Constant } \\
\text { Brand }\end{array}$ & 4.695 & & & \\
$\begin{array}{c}\text { Awareness } \\
\text { Brand }\end{array}$ & 0.425 & 5.442 & 2.00030 & 0.000 \\
Loyalty & 0.458 & 5.124 & 2.00030 & 0.000 \\
\hline
\end{tabular}

Source: Research Data, Processed 2021

In the regression equation above, the constant $(\mathrm{Y})$ is 4,695. This means that if the variables of brand awareness and brand loyalty are valued at zero, the purchase decision is 4,695. The brand awareness variable (X1) is a variable that affects purchasing decisions with a coefficient value of 0.425 . This means that brand awareness has a positive influence on purchasing decisions and explains that if brand awareness is higher, purchasing decisions will also increase. The brand loyalty variable (X2) is a variable that influences purchasing decisions with a coefficient value of 0.458 . This means that brand loyalty has a positive influence on purchasing decisions and explains that if brand loyalty is higher, purchasing decisions will also increase. 
Table 3. Determinant Coeficient

\begin{tabular}{ccccc}
\multicolumn{5}{c}{ Model Summary } \\
\hline Model & $\mathrm{R}$ & \multicolumn{1}{c}{ R Square } & Adjusted R Square & Std. Error of the Estimate \\
\hline 1 & $.876^{\mathrm{a}}$ &, 767 &, 760 & 1,071
\end{tabular}

Source: Research Data, Processed 2021

To find out whether there is an influence of the independent variable simultaneously with the dependent variable, it can be seen from the magnitude of the coefficient of determination (R2) found in the Adjusted R Square of 0.760. This means that the ability of the independent variable in explaining the dependent variable is $76 \%$, the remaining $24 \%$ is explained by other variables not discussed in this research such as brand association, perceived quality, etc.

Table 4. F Test

\begin{tabular}{lccccc}
\multicolumn{7}{c}{ Anova $^{\mathrm{b}}$} \\
\hline \multicolumn{1}{c}{ Model } & Sum Squares & Df & Mean Square & F & Sig. \\
\hline 1. Regression & 227,131 & 2 & 113,566 & 99,032 &, 000 \\
Residual & 68,805 & 60 & 1,147 & & \\
Total & $\mathbf{2 9 5 , 9 3 7}$ & $\mathbf{6 2}$ & & & \\
\hline
\end{tabular}

Source: Research Data, Processed 2021

Based on data analysis performed using the computer program tool SPSS for Windows version 21 , it is found that $f$ count is 99.032 with a significance of 0.000 . Based on that the result $\mathrm{Ho}$ is rejected and $\mathrm{H} 2$ is accepted because it has a calculated $\mathrm{f}$ value of 99.032> f table of 3.15 and a significance value of $0.000<0.05$. And the conclusion explains that brand awareness (X1), and brand loyalty (X2) have a significant effect on purchasing decisions (Y).

Table 5. T Test

\begin{tabular}{|c|c|c|c|c|c|c|c|}
\hline \multirow[t]{2}{*}{ Model } & \multicolumn{2}{|c|}{$\begin{array}{l}\text { Unstandardized } \\
\text { Coefficients }\end{array}$} & \multirow{2}{*}{$\begin{array}{c}\text { standardized } \\
\text { Coefficients } \\
\text { Beta }\end{array}$} & \multirow[b]{2}{*}{$\mathrm{T}$} & \multirow[b]{2}{*}{ Sig. } & \multicolumn{2}{|c|}{$\begin{array}{c}\text { Collinearity } \\
\text { Statistics }\end{array}$} \\
\hline & $\mathrm{B}$ & $\begin{array}{l}\text { Std. } \\
\text { Error }\end{array}$ & & & & Tolerance & VIF \\
\hline 1. (Constant) & 4,695 & 2,264 & & 2,074 & & & \\
\hline $\begin{array}{l}\text { Brand } \\
\text { awareness }\end{array}$ &, 425 & 0,78 & ,487 & 5,442 & & ,484 & 2,065 \\
\hline $\begin{array}{l}\text { Brand } \\
\text { Loyalty }\end{array}$ & ,458 & ,089 & ,458 & 5,124 & & ,484 & 2,065 \\
\hline
\end{tabular}

Source: Research Data, Processed 2021

The results of the brand awareness test (X1) obtained a significance value of 0.000 with a $\mathrm{t}$ value of 5.442. Ho is rejected and $\mathrm{H} 1$ is accepted because the $\mathrm{t}$ value is 5.442> t table is 2,00030 and the significance value is $0.000<0.05$. This shows that brand awareness (X1) has a positive and significant effect on consumer purchasing decisions $(\mathrm{Y})$.

The results of the brand loyalty test (X2) obtained a significance value of 0.000 with a $t$ value of 4.353. Ho is rejected and $\mathrm{H} 1$ is accepted because the $\mathrm{t}$ value is 5,124>t table is 2,00030 and the significance value is $0.000>0.05$. This shows that brand loyalty (X2) has a positive and 
significant effect on consumer purchasing decisions (Y).

\section{Discussion}

\section{The Influence of Brand Awareness on Purchasing Decisions}

In the brand awareness variable, the average respondent gave a very agreeable answer to the statement items in the brand awareness variable, which means that consumer brand awareness of high tonnes cement products and when consumers want cement, it will immediately cross the Semen Tonasa brand. According to Sasmita and Suki (2015), brand awareness is how consumers associate brands with certain products they want. Huang \& Sarigöllü (2014) said that high brand awareness can influence consumer decisions to use these products. As is the case with the consumer purchasing decisions of Semen Tonasa in Pangkep Regency, which is influenced by the extent to which consumers remember a brand. Many things can make consumers think of their products, such as the taste and quality they have (Wardana \& Maulana, 2019).

\section{The Effect of Brand Loyalty on Purchasing Decisions}

In the brand loyalty variable, the average respondent gives a very agreeable answer to the statement items in the Brand Loyalty variable, which means that consumer Brand Loyalty towards high tonnes cement products and consumers will be loyal to the Semen Tonasa brand product so that consumers when they want to buy cement, back to buy Semen Tonasa products. Brand loyalty is a measure of customer relationship to a brand. This measure describes whether it is possible for consumers to switch to another brand, especially if the brand has experienced changes in both price and other attributes (Mustafa et al., 2018). Because consumers are sensitive to the ups and downs of a product's price. The result can be reduced consumer loyalty in the purchasing power of a product. So there needs to be a sense of satisfaction that is given if a product has increased in price so that consumers can be loyal again, as expressed (Griffin and Ebert, 2007), "brand loyalty is a regular consumer buying pattern based on satisfaction with certain products".

This result is not in accordance with the initial prediction stated in the first research hypothesis (H1). Which states that brand awareness is a variable that has a dominant influence on the purchasing decision of Semen Tonasa. From the results of research conducted by observing and distributing questionnaires to the final consumers of PT Semen Tonasa in Pangkep Regency for 2 months, it was found that the variable that had the most dominant influence was brand loyalty with a regression coefficient value of 0.458 with a $t$ value of 4.353 , which shows that the more positive the value of brand loyalty towards tonnatic cement products, the higher the possibility to purchase tonnage cement products. On the other hand, the more negative the value of brand loyalty towards tonnatic cement products, the less likely it will be to purchase tonnes cement products (Natsir, 2019).

These results have implications for the need for marketers of Semen Tonasa products to maintain and increase consumer brand loyalty to Semen Tonasa products and if marketers have limited resources, then in the context of this study these resources should only be directed and allocated to increase consumer loyalty which will lead to repeat purchases (Haeruddin \& Haeruddin, 2020;227; Porral \& Levy-Mangin, 2016:679) 


\section{CONCLUSION}

Based on the research that has been done, the conclusion can be drawn from the results of the analysis and discussion as follows: 1) Brand awareness and brand loyalty have a positive and significant effect simultaneously on consumer purchasing decisions of PT Semen Tonasa in Pangkep Regency, and 2) Brand Loyalty is the most dominant variable affecting consumer purchasing decisions of PT Semen Tonasa in Pangkep Regency.

\section{REFERENCES}

Aaker, D. A. (2013). Manajemen Ekuitas Merek. Alih Bahasa: Aris Ananda.

Cobb-Walgren, C.J., Ruble, C.A., \& Donthu, N. (2013). Brand Equity, Brand Preference, and Purchase Intent. Journal of Advertising. Pages 25-40.

Durianto, D. (2011). Strategi Menaklukkan Pasar Melalui Riset Ekuitas dan Perilaku Merek. Cetakan XX. Jakarta: PT. Gramedia Pustaka Utama.

Gambetti, R., Biraghi, S., Schultz, D.E., \& Graffina, G. (2016). Brand wars: consumer-brand engagement beyond client-agency fights. Journal of Strategic Marketing, 24:2, 90-103

Griffin, R.W \& Ebert, R.J. (2007). BISNIS, Edisi Kedelapan, Jilid 1, Jakarta: Penerbit Erlangga.

Gurley, T., Lin, S. \& Ballou, S. (2005), "Consumer decision process modeling: how leaders can better understand buyers' choices", Strategy \& Leadership. Vol. 33 No. 3, pp. 30-40.

Haeruddin, M. I. M. (2017). Should I stay or should I go? Human Resource Information System implementation in Indonesian public organizations. European Research Studies, 20(3A), 989.

Haeruddin, M. I. M., Farhansyah, A., Haeruddin, M. I., \& Mansur, M. A. R. (2020). We could be so good together. International Journal of Educational Administration, Management, and Leadership, 77-84.

Haeruddin, M. I. W., \& Haeruddin, M. I. M. (2020). The Effect of Customer Satisfaction on Customer Loyalty in Kartu As Products in Makassar City. Jurnal Ad'ministrare, 7(2), 227-234.

Hasan, A. (2014). Marketing dan Kasus-Kasus Pilihan. Jakarta: CAPS.

Helgesen, Ø. (2006). Are Loyal Customers Profitable? Customer Satisfaction, Customer (Action) Loyalty and Customer Profitability at the Individual Level. Journal of Marketing Management. Volume 22. Page 245-266.

Huang R., \& Sarigöllü E. (2014) How Brand Awareness Relates to Market Outcome, Brand Equity, and the Marketing Mix. In: Choi TM. (eds) Fashion Branding and Consumer Behaviors. International Series on Consumer Science. Springer, New York, NY.

Kotler, P. \& Armstrong, G. (2012). Prinsip-Prinsip Pemasaran. Edisi ke 13. Jilid 1. Jakarta: Erlangga.

Mudambi, S. (2002). Branding importance in business-to-business markets: Three buyer clusters. Industrial Marketing Management. Vol 31. Issue 6. Pages 525-533.

Musa, M. I. (2017). Bundling Pricing Strategy on Purchasing Decision: A Case of Indihome Product. Management, 7(3), 126-130.

Mustafa, M. Y., Mustafa, F., Mustafa, R., \& Mustafa, R. (2018). Japanese Enterprises Role on SMEs Development in Indonesia: Inside Tobiko Export and Import. Hasanuddin Economics and Business Review, 2(2), 83-95.

Natsir, U. D. (2019). Pengaruh Kompensasi Terhadap Produktivitas Kerja Karyawan Pada CV Mote Water Filterindo di Kota Makassar. Economix, 6(2). 
Volume 4, Issue 2, March 2021 Page. 211- 218

Porral, C.C., \& Levy-Mangin, J.P. (2016), "Food private label brands: the role of consumer trust on loyalty and purchase intention". British Food Journal. Vol. 118 No. 3, pp. 679696.

Prasad, S., Garg, A. \& Prasad, S. (2019), "Purchase decision of generation $Y$ in an online environment", Marketing Intelligence \& Planning. Vol. 37. No. 4, pp. 372-385.

Sasmita, J., \& Suki, N.M. (2015), Young Consumer's Insights on Brand Equity: Effects of Brand Association, Brand Loyalty, Brand Awareness, And Brand Image, Journal of Retail \& Distribution Management. Vol. 43 No. 3: 276-292.

Schiffman, L.G., \& Kanuk L.L. (2010). Perilaku Konsumen. Jakarta: PT. INDEK.

Shimp, T.A. (2003). Periklanan Promosi \& Aspek Tambahan Komunikasi

Stankevich, A. (2017). Explaining the Consumer Decision-Making Process: Critical Literature Review. Journal of International Business Research and Marketing. Volume 2. Issue 6.

Supranto, J. \& Limakrisna, N. (2011). Perilaku Konsumen dan Strategi Pemasaran. Edisi Kedua. Jakarta: Mitra Wacana Media.

Wardana, M. I., \& Maulana, M. I. (2019). Pengaruh Biaya Promosi Terhadap Penjualan Mobil Merek Toyota Yaris (Studi Kasus: PT Hadji Kalla Makassar). Economix, 4(2).118-128. 